\title{
Hepatoprotective and Antioxidant Activity of Ethanol Extracts of Dipterocarpus turbinatus (Dipterocarpaceae) from Tripura
}

\author{
Diptanu Biswas ${ }^{1 *}$, T. Shivraj Gouda ${ }^{2}$ and Narayanswamy Lachmanan Gowrishankar ${ }^{3}$ \\ 1Department of Pharmacognosy, C E S College of Pharmacy, NH-7, Chinnatekur, \\ Kurnool - 518218, Andhra Pradesh, India \\ 2Department of Pharmacology, NET Pharmacy College, Raichur - 584103, Karnataka, India \\ ${ }^{3}$ Department of Pharmacognosy, Prime College of Pharmacy, Erattayal, Kodumbu, \\ Palakkad - 678551, Kerala, India
}

\begin{abstract}
Ethanol extracts from the bark of Dipterocarpus turbinatus (EEDT) was evaluated for its hepatoprotective activity by paracetamol and carbon tetrachloride induced hepatotoxicity in rats. Hepatotoxicity was done by using carbon tetra chloride $(2 \mathrm{ml} / \mathrm{kg}$ ) and paracetamol $(3 \mathrm{gm} / \mathrm{kg})$ in rats. $200 \mathrm{mg} / \mathrm{kg}$ and $400 \mathrm{mg} / \mathrm{kg}$ of ethanol extracts of $D$. turbinatus (EEDT) was used as test drugs while silymarin $(50 \mathrm{mg} / \mathrm{kg})$ used as a standard. Blood was collected by retro orbital pluxes and various biochemical parameters were evaluated related to liver disorder. Various parameters like SGOT, SGPT, ALP, cholesterol, serum bilirubin and levels significantly decreased with the dose dependence manner for EEDT as compared to paracetamol and $\mathrm{CCl}_{4}$ induced hepatotoxicity in rats. Total protein level was significantly increasing to test drug treated group as compared to the toxic control. Anti oxidant potency of drug was determined by various in-vitro methods and the drug extracts have shown positive results. Therefore, we conclude that it can be used for the treatment of hepatic damage where anti oxidant property is supported for its hepatoprotective activity.
\end{abstract}

Keywords: Anti oxidant, Dipterocapus tubinatus, Hepatoprotective, Silymarin

\section{Introduction}

Liver is vital organ in human body that perform detoxification of exogenous xenobiotics, infection and regulate various biochemical enzymes for metabolisms thus help to fight against disease ${ }^{1}$. Liver disease is a worldwide problem which is caused by various agents like alcohol, drugs and chemicals ${ }^{2}$. In spite of phenomenal growth of modern medicine there are no synthetic drugs available for the treatment of hepatic disorder. However herbal formulation claimed to have beneficial effect on liver disorder ${ }^{3}$. Preliminary phyto chemical analysis of the extracts shows presence of phenol and flavonoids ${ }^{4}$ which is known to be hepatoprotective and anti oxidant activity. Free radicals like ROS and NOS due to the special characters can initiate the lipid peroxidation, break nucleic acid strands and oxidize virtually all molecules in the biological membrane resulting in the injury of liver. Thus anti oxidant effects drug can prevent liver's oxidative damage ${ }^{5}$.

Dipterocarpus turbinatus is a large woody plant height of $100-120 \mathrm{ft}$. and a girth of $8-15 \mathrm{ft}$. It is found

\footnotetext{
*Author for correspondence

Email: diptanu69@gmail.com
} 
in the tropical forests of Tripura, Assam and Andaman. D. turbinatus is used traditionally as anti diarrhoeal, astringent, wound healer, antiulcer, burns, tuberculoid leprosy ${ }^{6-8}$. In Ayurveda, Asanadi gana was one of the ingredients out of 23 plants which were used in the diabetic treatment ${ }^{9}$. Tribal people of Tripura use $D$. turbinatus plant and plant derived product for various purposes. This drug possess anti oxidant activity ${ }^{10}$, aqueous extracts of the plant used for reducing gum and tooth ache ${ }^{11}$. It shows cyto-toxic activity ${ }^{12}$ and other species of the plants also shows anti cancer properities ${ }^{13}$. In this work we have done the hepatoprotective and anti oxidant activity of ethnolic extract of $D$. turbinatus bark by in vivo and in vitro method respectively.

Barks were procured from wild source from the forest of Tripura. The plant material was authentified by Prof P. Jayaraman, M.Sc., Ph.D., Director PARC., Chennai. With reference number (PARC/2012/1277). The specimen was preserved at the herbarium of the institute.

\subsection{Chemical and Reagent}

Paracetamol and Silymarin were procured from the Micro Lab Ltd., India. Standard biochemical kits \{Serum Glutamate Oxaloacetate Transaminase (SGOT), Serum Glutamate Pyruvate Transaminase (SGPT), Serum Alkaline Phosphate (ALP), Bilirubin, Protein kits\} were procured form Agappe diagnostics Ltd, Kerala, India. DPPH was procured from Hi Media Mumbai. All other reagents for the study were procured from SD fine lab, Mumbai, India. Remi research centrifuge was used for centrifugation purpose. Mispa excel semi autoanalyzer made of Agappe diagnostic Ltd., Kerala, India and double beam UV-Visible spectrophotometer of Lab India, were used for various analyses.

Coarsely powdered dried bark of $500 \mathrm{~g}$ was extracted up to exhaustion with petroleum ether, chloroform, and ethanol (70\%) using soxhlet apparatus. Ethanol extracts $(18 \% \mathrm{w} / \mathrm{w})$ thus obtained was dried under controlled temperature and was selected for the study.

\section{Experimental Animals}

The animals (Wistar albino rats for hepatoprotective activity and albino Mice for acute toxicity) were kept at Standard environmental conditions for 7 days before the experiments. All the animals were maintained under strict hygienic conditions with normal feed and water. The entire animals were utilized for the studies and used according to the protocol approved by (No. IAEC/CESCOP/2016-07) Institutional Animal Ethics Committee. For each hepatoprotective activity 5 groups were made for both models (paracetamol and carbon tetrachloride) containing 6 animals. Group I serves as vehicle control, group II contains hepatotoxin, group III contains standard (Silymarin), group IV and V serve as drugs treated $(200 \mathrm{mg} / \mathrm{kg} \& 400 \mathrm{mg} / \mathrm{kg}$ of EEDT) group.

Acute toxicity for EEDT was determined by the method adapted by CPCSEA, Government of India, - acute toxic class method (OCED Guideline no. 423, Annexure-2d) in albino mice. The mortality was observed after oral administration of $2000 \mathrm{mg} / \mathrm{kg}$ b.w of test sample ${ }^{14}$. Common side effects like mild diarrhea, weight loss and depression of treated groups of animals were recorded within the one week of observation ${ }^{15}$.

Group I (vehicle control) was given 2\% acacia suspension in normal saline, group II received paracetamol $(3 \mathrm{gm} / \mathrm{kg})^{16}$ as a single dose at $0 \mathrm{hr}$ followed by vehicle for $1 \mathrm{hr}, 24 \mathrm{hr}, 48 \mathrm{hr}$. Group III received paracetamol $(3 \mathrm{gm} / \mathrm{kg} / \mathrm{p} . \mathrm{o})$ as a single dose at $0 \mathrm{hr}$ followed by Silymarin $(50 \mathrm{mg} / \mathrm{kg})$ for $1 \mathrm{hr}, 24 \mathrm{hr}, 48 \mathrm{hr}$. Group IV and V received paracetamol $3 \mathrm{gm} / \mathrm{kg}$ at $0 \mathrm{hr}$ followed by drug extracts $200 \mathrm{mg} / \mathrm{kg}$ and $400 \mathrm{mg} / \mathrm{kg}$ at $1 \mathrm{hr}, 24 \mathrm{hr}, 48 \mathrm{hr}$. At $72^{\text {nd }} \mathrm{hr}$, blood was collected from animals and biochemical parameters were evaluated related to liver disorder to check the therapeutic effects of the drug extracts ${ }^{17}$. All the dosage has administrated by oral route.

\subsection{Carbon Tetra Chloride Induced Hepatotoxicity}

Group I serves as (-ve) control and were received $1 \mathrm{ml}$ $2 \%$ acacia solution for 5 days and olive oil $2 \mathrm{ml} / \mathrm{kg}$ on $2^{\text {nd }}$ and $3^{\text {rd }}$ day. Group II serves as (+ve) control, receiving acacia suspension for 5 days; Group III receiving standards Silymarin 50mg/kg for 5 days; Group (IV \& V) receiving EEDT $200 \mathrm{mg} / \mathrm{kg} \& 400 \mathrm{mg} / \mathrm{kg}$ for 5 days. $\mathrm{CCl}_{4}$ was administrated by IP route by mixing with olive oil (1:1) and all other treatment was given by oral route. On $2^{\text {nd }}$ and $3^{\text {rd }}$ day group II, III, IV \& V received carbon tetra chloride at a dose $2 \mathrm{ml} / \mathrm{kg}^{18} 30$ minutes later 
of drugs treatment. Blood samples were collected on $6^{\text {th }}$ day by retro orbital plexus ${ }^{19}$ route for evaluating various biochemical parameters.

Assessments of liver function were done by collecting blood from retro orbital puncture. Blood was centrifuged at $4000 \mathrm{rpm}$ for $15 \mathrm{~min}$ and serum was collected. Various biochemical parameters like SGOT, SGPT, serum ALP, total cholesterol, total bilirubin and total protein were evaluated using biochemical kits ${ }^{20}$.

The animals were sacrificed and liver were collected and washed with normal saline. Isolated liver were stored in 40\% formalin solution and histopathology was done to evaluate the details change hepatic cell structure in each group microscopically for both the models.

\subsection{Anti Oxidant Activity}

\subsubsection{DPPH (2, 2-diphenyl-1-picrylhydrazyl) Radical Scavenging Activity}

DPPH scavenging activity was measured according to the method of Sanjay Rai et al. ${ }^{21}$ with some modifications. The free radical-scavenging activities of all samples were estimated in terms of hydrogen donating or radical scavenging ability. A Solution of $0.1 \mathrm{mM} \mathrm{DPPH}$ was prepared in ethanol. $1 \mathrm{ml}$ of this solution was added to 3 $\mathrm{ml}$ of all the extracts in water at different concentrations $(1-10 \mu \mathrm{g} / \mathrm{ml})$. Thirty minutes later the absorbance was measured at $517 \mathrm{~nm}$. Ascorbic acid is used as standard antioxidant. The results expressed as $\mathrm{IC}_{50}$ or inhibitory concentration 50 value.

\subsection{Reducing Ability}

Reducing power of EEDT was determined based on the ability of anti oxidant to form complex with potassium ferricyanide, TCA and $\mathrm{FeCl}_{3}$. Add different concentration of sample(s) in $1 \mathrm{ml}$ of distilled water in order to get $1 \mu \mathrm{g}, 2 \mu \mathrm{g}, 4 \mu \mathrm{g}, 8 \mu \mathrm{g}$ and $10 \mu \mathrm{g} / \mathrm{ml}$ concentration. A test tube also makes as control (without any test sample). Add phosphate buffer (2.5 ml, 0.2 M, pH 6.6) and potassium ferricyanide $(2.5 \mathrm{ml}, 1 \%)$ to the sample. The mixture was incubated at $50 \mu \mathrm{C}$ for $20 \mathrm{~min}$. Portions $(2.5$ $\mathrm{ml})$ of trichloroacetic acid (10\%) added to the mixture and centrifuged at $3000 \mathrm{rpm}$ for 10 minutes. The upper layer of the mixture solution $(2.5 \mathrm{ml})$ was mixed with distilled water $(2.5 \mathrm{ml})$ and $0.1 \%$ ferric chloride $(0.5$ $\mathrm{ml})$. The absorbance (OD) was measured at $700 \mathrm{~nm}^{22}$ by using Ascorbic as standard. The \% reducing power was calculated by using by conventional formula.

\subsection{Superoxide Anion Scavenging Activity}

The reaction mixture contains $100 \mu$ riboflavin $(20 \mu \mathrm{g} /$ $\mathrm{ml})$ solution, $200 \mu \mathrm{l}$ EDTA $(12 \mathrm{mM})$ solution, $200 \mu \mathrm{l}$ Methanol and $100 \mu \mathrm{l}$ NBT $(0.1 \mathrm{mg})$ solution in a test tube. The reaction mixture was diluted up to $3 \mathrm{ml}$ with phosphate buffer $(50 \mathrm{mM}, \mathrm{pH} 7.6)$. The absorbance of the mixture solution was measured at $560 \mathrm{~nm}$ using phosphate buffer as blank after illumination for $15 \mathrm{~min}$. The OD was taken as control reading. Add different concentration $(1 \mu \mathrm{g}, 2 \mu \mathrm{g}, 4 \mu \mathrm{g}, 8 \mu \mathrm{g}$ and $10 \mu \mathrm{g} / \mathrm{ml})$ of samples in a test tube containing $100 \mu \mathrm{l}$ Phosphate buffer. Add with $100 \mu \mathrm{l}$ riboflavin, $200 \mu \mathrm{l}$ EDTA, $200 \mu \mathrm{l}$ ethanol and $100 \mu \mathrm{l}$ NBT solution in respective test tubes. Then the reaction mixture was diluted up to $3 \mathrm{ml}$ with phosphate buffer. The absorbance of the solution was measured after illumination for $5 \mathrm{~min}$ at $590 \mathrm{~nm}$. L-Ascorbic acid was used as a standard ${ }^{23}$. Result was expressed as Inhibitory concentration 50 for the test drug.

Nitric oxide scavenging activity of extracts was determined by using Griess reagent ( $1 \%$ sulphonilamide, $2 \%$ phosphoric acid and 1\% naphthyl ethylene diamine di hydrochloride). Reaction mixture containing $3 \mathrm{ml}$ of sodium nitroprusside $(10 \mathrm{M} . \mathrm{mol})$ in phosphate buffer and test extracts in different concentrations $(1 \mu \mathrm{g}, 2 \mu \mathrm{g}$, $4 \mu \mathrm{g}, 8 \mu \mathrm{g}$ and $10 \mu \mathrm{g} / \mathrm{ml}$ ) were incubated at $25^{\circ} \mathrm{C}$ for 150 minutes. Control was prepared by omitting the sample. After incubation, $0.5 \mathrm{ml}$ of Griess reagent was added and the absorbance was measured at 546nm using UVvisible spectrophotometer ${ }^{24}$. Percentage inhibition was calculated and the activity was expressed as an inhibition concentration $50\left(\mathrm{IC}_{50}\right)$.

\section{Statistical Analysis}

Data were expressed as Mean values \pm SEM. The differences between the groups were analyzed by one way ANOVA and compare with toxic group. A value ${ }^{\star} \mathrm{p}<$ 0.05 was considered as statistically significant. 


\subsection{Acute Toxicity Study $\left(\operatorname{LD}_{50}\right)$}

Acute toxicity study was carried out according to method of OECD 423 for EEDT. Mortality was not observed at $2000 \mathrm{mg} / \mathrm{kg}$ in mice. Thus $2000 \mathrm{mg} / \mathrm{kg}$ was considered as cut off dose. Thus $1 / 10^{\text {th }}$ and $1 / 5^{\text {th }}(200 \mathrm{mg} / \mathrm{kg}$ and $400 \mathrm{mg} / \mathrm{kg}$ ) dose were taken as effective dose for all further in-vivo studies.

\subsection{Effects of Ethanol Extracts of $D$. turbinatus on Various Biochemical Parameters Associated with Liver Toxicity}

Animal treated with $200 \mathrm{mg} / \mathrm{kg}$ and $400 \mathrm{mg} / \mathrm{kg}$ P.O of ethanol extracts from $D$. turbinatus barks exhibit a significant $\left({ }^{*} \mathrm{p}<0.05\right)$ reduction in various biochemical parameters. In paracetamol induced and carbon tetra chloride induced groups, there was an increase in the level of SGOT, SGPT, ALP, serum bilirubin and decrease in the level of total proteins. Treatment with the extracts $200 \mathrm{mg} / \mathrm{kg}$ and $400 \mathrm{mg} / \mathrm{kg}$ P.O take down to normal in the level of SGOT, SGPT, ALP, Cholesterol and serum bilirubin and increase the level of total proteins. The results were explained in Table 1 and Table 2. D. turbinatus bark extracts showed the degree of protection with the higher dose.

Histology of liver was done for all groups to find out change in liver architecture; like central vein, cytoplasm, nature of polygonal hepatocytes with their round nucleus and cytoplasm. Blood cell infiltration in hepatic vein, sinusoidal area and aggregation of Kuffer cells surrounding the central veins was also observed. Figure 1(a) and 2(a) shows the histopathology of the liver of untreated animals with normal hepatic vein, with less sinusoidal space polygonal hepatocytes without any ballooning. Figure 1(b) intoxicated with paracetamol shows damage in hepatic cell enlargement sinusoidal space and with infiltration of blood cell in hepatic vein, where as Figure 2(b) intoxicated with $\mathrm{CCl}_{4}$ shows so much damage in the cellular system in liver cell. In both Figure 1(c) and 1(d) standard drug treated animal able to normalize the hepatic cell with less sinusoidal space, polygonal shape of kuffer cell, and hepatic vein with less blood cell in filtration. Figure 1(d) and 1(e) shows test drug treated with $200 \mathrm{mg} / \mathrm{kg}$ and $400 \mathrm{mg} / \mathrm{kg}$, in paracetamol induced hepatotoxic animals liver, where we can see improvement of hepatocyte, sinusoidal space and hepatic vein as compared to the toxic (Paracetamol treated group) group. Figure $2(\mathrm{~d})$ and $2(\mathrm{e}) \mathrm{CCl}_{4}$ induced hepatotoxic animals liver treated with $200 \mathrm{mg} / \mathrm{kg}$ and $400 \mathrm{mg} / \mathrm{kg}$ EEDT with normalized liver cell.

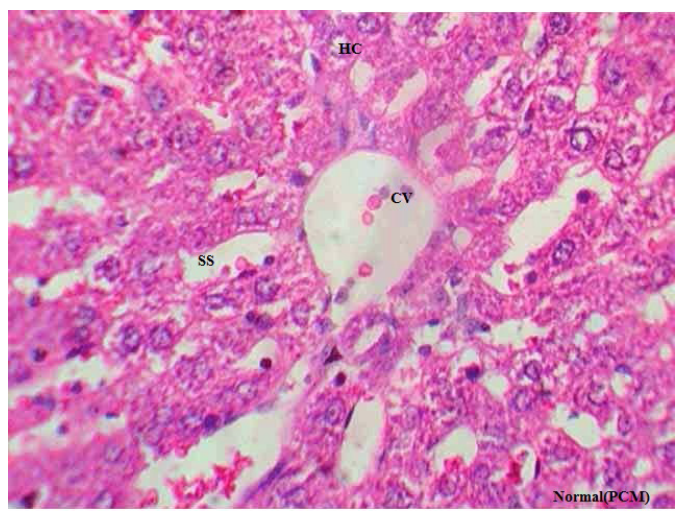

(a)

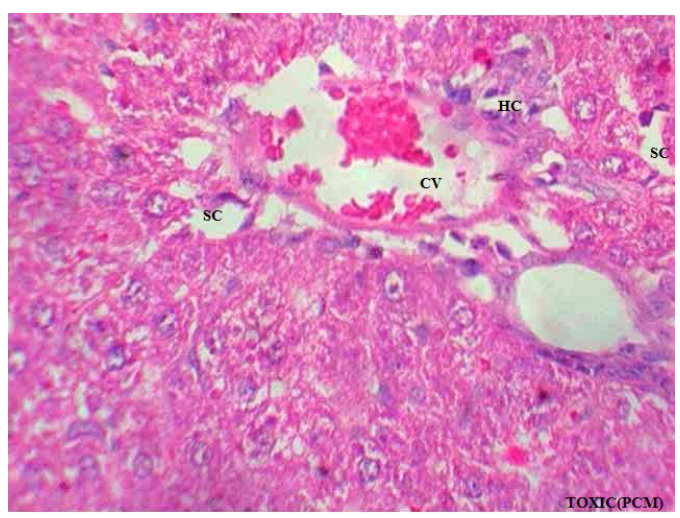

(b)

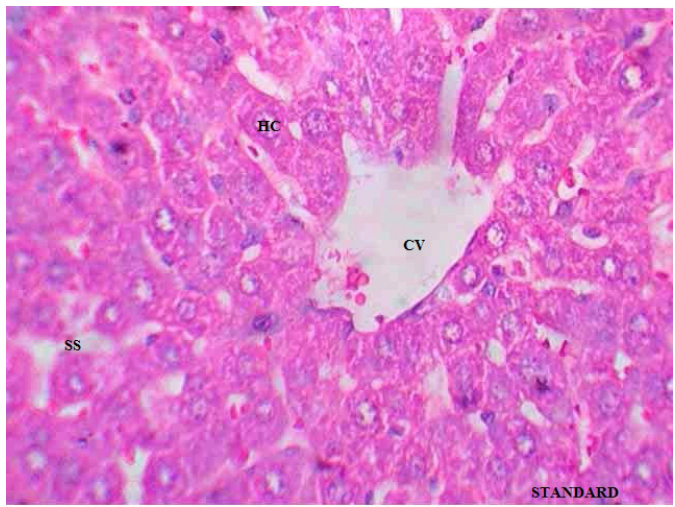

(c) 


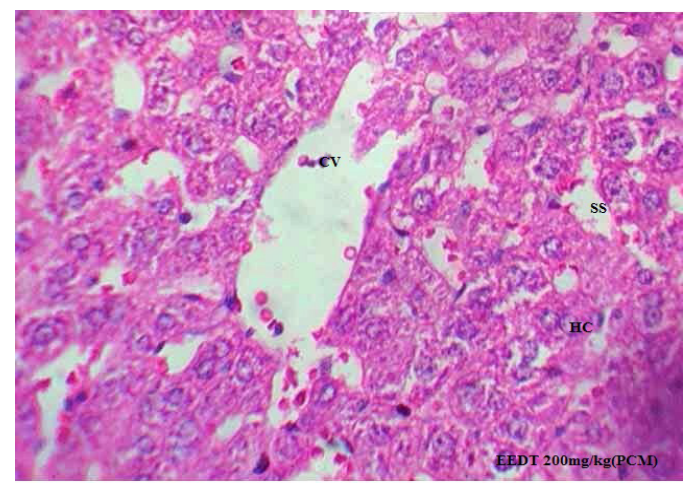

(d)

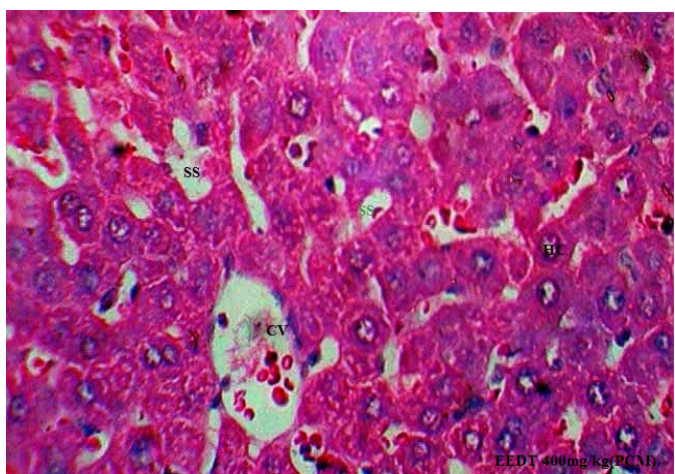

(e)

Fig. 1. (a) Normal liver section of rats (400X), (b) Liver section of rats (400X) intoxicated with Paracetamol (3gm/ $/ \mathrm{kg})$, (c) Liver section of rats $(400 X)$ intoxicated with Paracetamol $(3 \mathrm{gm} / \mathrm{kg})$ and treated with Silymarin $(50 \mathrm{mg} / \mathrm{kg})$, (d) Liver section of rats (400X) intoxicated with Paracetamol $(3 \mathrm{gm} / \mathrm{kg})$ and treated with EEDT $(200 \mathrm{mg} / \mathrm{kg})$, (e) Liver section of rats (400X) intoxicated with Paracetamol (3gm/ $\mathrm{kg}$ ) and treated with EEDT $(400 \mathrm{mg} / \mathrm{kg})$.

Table 1: Hepatoprotective activity of ethanol extracts from barks of D.turbinatus against paracetamol induced hepatotoxicity

\begin{tabular}{|c|c|c|c|c|c|c|c|}
\hline \multirow[b]{2}{*}{ Groups } & \multirow[b]{2}{*}{ Treatment } & \multicolumn{6}{|c|}{ Parameters } \\
\hline & & SGOT (U/I) & SGPT (U/I) & APL (U/I) & $\begin{array}{c}\text { Cholesterol } \\
\text { (mg/dl) }\end{array}$ & $\begin{array}{l}\text { Total Bilirubin } \\
(\mathrm{mg} / \mathrm{dl})\end{array}$ & $\begin{array}{l}\text { Total Protein } \\
\text { (g/dl) }\end{array}$ \\
\hline Group I & Normal control & $\begin{array}{l}119.6 \pm \\
5.431\end{array}$ & $\begin{array}{l}63.61 \pm \\
3.89\end{array}$ & $\begin{array}{l}99.33 \pm \\
5.18\end{array}$ & $\begin{array}{l}108.5 \pm \\
6.083\end{array}$ & $\begin{array}{l}0.9783 \pm \\
0.023\end{array}$ & $\begin{array}{l}8.823 \pm \\
0.445\end{array}$ \\
\hline Group II & $\begin{array}{c}\text { Toxic } \\
\text { (paracetamol) }\end{array}$ & $\begin{array}{l}588.5 \pm \\
45.18\end{array}$ & $\begin{array}{l}387.117 \pm \\
11.76\end{array}$ & $\begin{array}{l}270.9 \pm \\
15.92\end{array}$ & $\begin{array}{l}253.3 \pm \\
11.65\end{array}$ & $\begin{array}{l}2.490 \pm \\
0.3002\end{array}$ & $\begin{array}{l}3.692 \pm \\
0.297\end{array}$ \\
\hline Group III & $\begin{array}{c}\text { Standard } \\
\text { (Paracetamol + } \\
\text { Silymarin) }\end{array}$ & $\begin{array}{l}121.7 \pm \\
3.584^{* * *}\end{array}$ & $\begin{array}{l}70.34 \pm \\
3.22^{* * *}\end{array}$ & $\begin{array}{l}92.61 \pm \\
4.152^{* *}\end{array}$ & $\begin{array}{l}107.8 \pm \\
4.738^{* * *}\end{array}$ & $\begin{array}{l}1.294 \pm \\
0.1190^{* * *}\end{array}$ & $\begin{array}{l}8.327 \pm \\
0.7873^{* * *}\end{array}$ \\
\hline Group IV & $\begin{array}{c}\text { Test (EEDT } \\
\text { 200mg/kg + } \\
\text { Paracetamol) }\end{array}$ & $\begin{array}{l}182.9 \pm \\
5.377^{* *}\end{array}$ & $\begin{array}{l}188.6 \pm \\
12.20^{* *}\end{array}$ & $\begin{array}{l}102.2 \pm \\
5.560^{* * *}\end{array}$ & $\begin{array}{l}169.9 \pm \\
7.757^{* *}\end{array}$ & $\begin{array}{l}0.5833 \pm \\
0.05463^{*}\end{array}$ & $\begin{array}{l}7.335 \pm \\
0.3618^{* *}\end{array}$ \\
\hline Group V & $\begin{array}{c}\text { Test (EEDT } \\
\text { 400mg/kg+ } \\
\text { Paracetamol) }\end{array}$ & $\begin{array}{l}165.3 \pm \\
1.65^{* * *}\end{array}$ & $\begin{array}{l}164.1 \pm \\
6.432^{* * *}\end{array}$ & $\begin{array}{l}79.81 \pm \\
7.969^{* * *}\end{array}$ & $\begin{array}{l}140.1 \pm \\
6.10^{* *}\end{array}$ & $\begin{array}{l}0.4567 \pm \\
0.0445^{* *}\end{array}$ & $\begin{array}{l}7.252 \pm \\
0.3225^{* *}\end{array}$ \\
\hline
\end{tabular}

Values are the mean \pm SEM six rats. Symbol represent statically significance ${ }^{* * *} \mathrm{P}<0.001 .,{ }^{* *} \mathrm{P}<0.01 .,{ }^{*} \mathrm{P}<0.05$ compared with toxic paracetamol group.

Table 2: Hepatoprotective activity of ethanol extracts from barks of D.turbinatus against Carbon tetra chloride induced hepato toxicity

\begin{tabular}{|c|c|c|c|c|c|c|c|}
\hline \multirow[b]{2}{*}{ Groups } & \multirow[b]{2}{*}{ Treatment } & \multicolumn{6}{|c|}{ Parameters } \\
\hline & & SGOT(U/I) & SGPT (U/I) & APL (U/I) & $\begin{array}{c}\text { Cholesterol } \\
\text { (mg/dl) }\end{array}$ & $\begin{array}{c}\text { Total } \\
\text { Bilirubin } \\
\text { (mg/dl) }\end{array}$ & $\begin{array}{c}\text { Total } \\
\text { Protein } \\
\text { (g/dl) }\end{array}$ \\
\hline Group I & Normal control & $\begin{array}{l}140.9 \pm \\
4.417\end{array}$ & $\begin{array}{l}78.98 \pm \\
4.296\end{array}$ & $\begin{array}{l}55.45 \pm \\
3.235\end{array}$ & $\begin{array}{l}119.0 \pm \\
5.235\end{array}$ & $\begin{array}{l}0.2327 \pm \\
0.0413\end{array}$ & $\begin{array}{l}5.975 \pm \\
0.2181\end{array}$ \\
\hline Group II & Toxic $\left(\mathrm{CCl}_{4}\right)$ & $\begin{array}{l}453.3 \pm \\
28.03\end{array}$ & $\begin{array}{l}243.0 \pm \\
12.71\end{array}$ & $\begin{array}{l}189.1 \pm \\
7.498\end{array}$ & $\begin{array}{l}189.1 \pm \\
7.498\end{array}$ & $\begin{array}{l}2.020 \pm \\
0.217\end{array}$ & $\begin{array}{l}9.239 \pm \\
0.4360\end{array}$ \\
\hline Group III & Standard (+ Silymarin) & $\begin{array}{l}136.0 \pm \\
13.15^{* * *}\end{array}$ & $\begin{array}{l}156.3 \pm \\
3.268^{* * *}\end{array}$ & $\begin{array}{l}125.4 \pm \\
2.474^{* *}\end{array}$ & $\begin{array}{l}125.4 \pm \\
2.474^{* * *}\end{array}$ & $\begin{array}{l}0.2733 \pm \\
0.02728^{* *}\end{array}$ & $\begin{array}{l}5.377 \pm \\
0.2397^{* * *}\end{array}$ \\
\hline Group IV & Test $\left(\mathrm{EEDT}+\mathrm{CCl}_{4}\right)$ & $\begin{array}{l}288.0 \pm \\
22.23 \mathrm{~ns}\end{array}$ & $\begin{array}{l}170.8 \pm \\
7.912^{* *}\end{array}$ & $\begin{array}{l}174.4 \pm \\
6.817^{* *}\end{array}$ & $\begin{array}{l}151.179 \pm \\
9.372^{*}\end{array}$ & $\begin{array}{l}1.827 \pm \\
0.1214^{* * *}\end{array}$ & $\begin{array}{l}6.118 \pm \\
0.389^{* *}\end{array}$ \\
\hline Group V & Test $\left(\mathrm{EEDT}+\mathrm{CCl}_{4}\right)$ & $\begin{array}{l}155.3 \pm \\
13.65^{* *}\end{array}$ & $\begin{array}{l}89.85 \pm \\
4.813^{* * *}\end{array}$ & $\begin{array}{l}131.2 \pm \\
1.404^{* * *}\end{array}$ & $\begin{array}{l}125.4 \pm \\
3.003^{* * *}\end{array}$ & $\begin{array}{l}1.192 \pm \\
0.025^{* * *}\end{array}$ & $\begin{array}{l}8.233 \pm \\
0.543^{* * *}\end{array}$ \\
\hline
\end{tabular}

Values are the mean \pm SEM six rats. Symbol represent statically significance ${ }^{* * *} \mathrm{P}<0.001 .,{ }^{* *} \mathrm{P}<0.01 .,{ }^{*} \mathrm{P}<0.05$ compared with toxic paracetamol group, Where Ns represent not significant. 


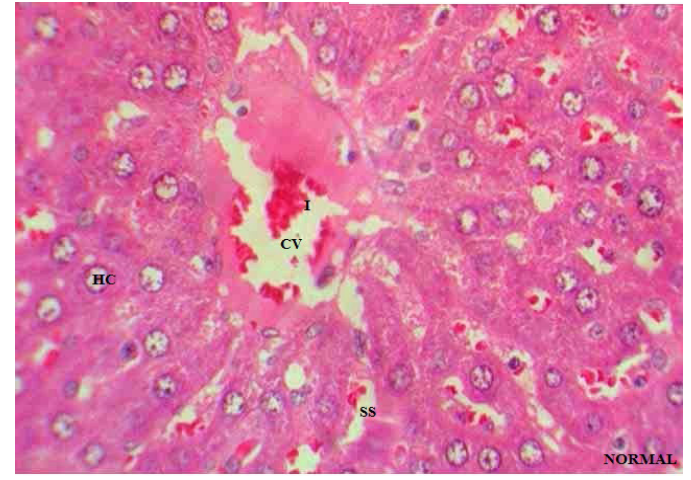

(a)

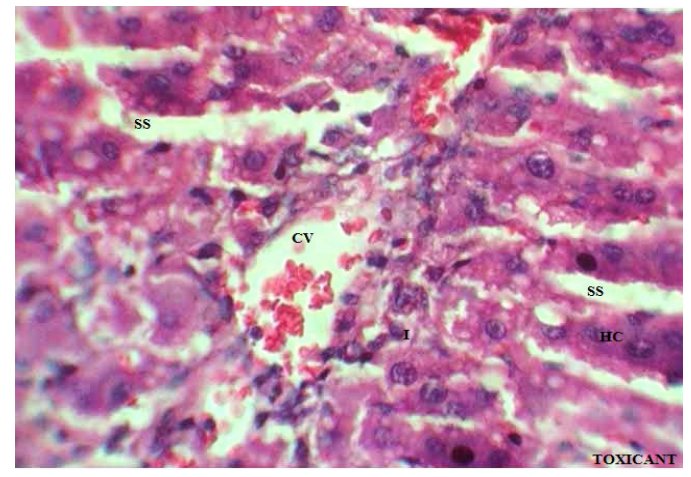

(b)

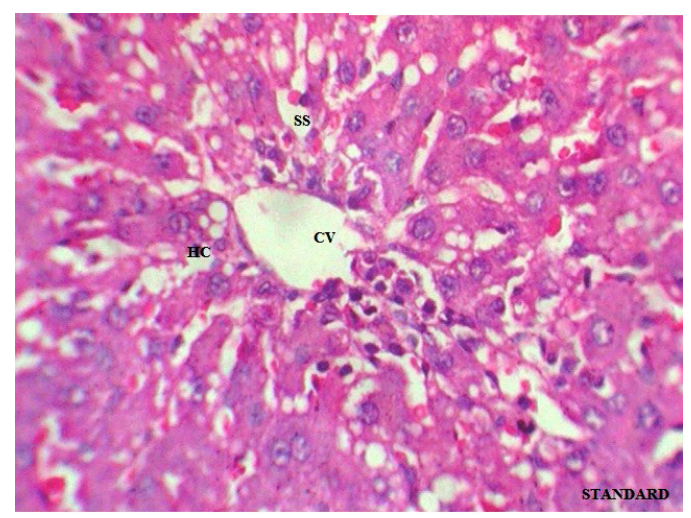

(c)

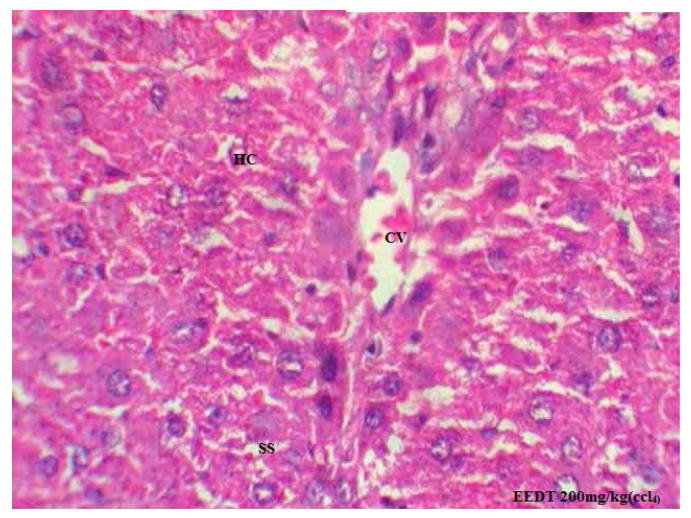

(d)

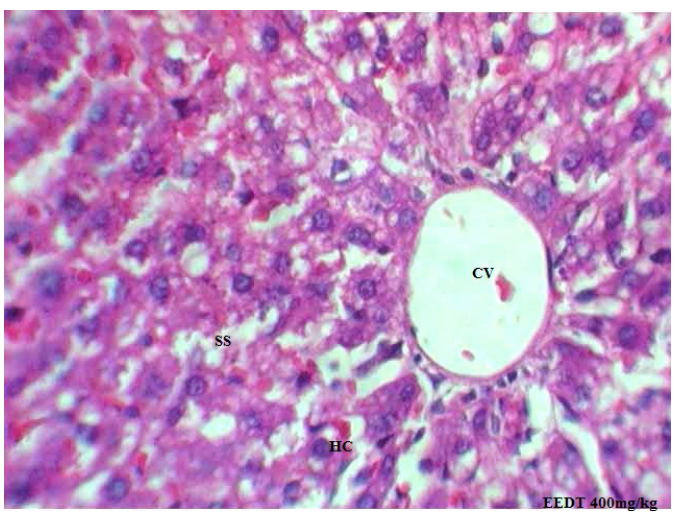

(e)

Fig. 2. (a) Normal liver section (400X), (b) Liver section of rats $(400 X)$ intoxicated with carbon tetrachloride $(2 \mathrm{ml} / \mathrm{kg})$. (c) Liver section of rats (400X) treated with Silymarin (50mg/ $\mathrm{kg})$ and intoxicated with Carbon tetrachloride $(2 \mathrm{ml} / \mathrm{kg})(\mathrm{d})$ Liver section of rats $(400 X)$ treated with EEDT $(200 \mathrm{mg} / \mathrm{kg})$ and intoxicated with Carbon tetrachloride $(2 \mathrm{ml} / \mathrm{kg})$, (e) Liver section of rats $(400 X)$ treated with EEDT $(400 \mathrm{mg} / \mathrm{kg})$ and intoxicated with Carbon tetrachloride $(2 \mathrm{ml} / \mathrm{kg})$.

\subsection{Anti Oxidant Activity}

D. turbinatus bark extracts posses a significant anti oxidant activity. Table 3 illustrates the results of anti oxidant activity by various in vitro anti oxidant methods.

Preliminary phyto chemical analysis of the extracts shows presence of phenol and flavonoids ${ }^{4}$ which is known to be hepatoprotective and anti oxidant activity. Anti oxidant capacity of the plant extracts may be helpful in the regeneration of hepatic cells from their oxidative damage and protect the liver cell from toxicants. Paracetamol is widely used as anti pyretic and analgesic. The metabolite of paracetamol N-acetyl-pbenzoquinonimine breaks sulphydryl group of proteins and causes liver damage ${ }^{25,26}$. $\mathrm{CCl}_{4}$ has been widely used as an indicator of the liver protective activity of drug ${ }^{27}$. $\mathrm{CCl}_{4}$ gets metabolised in liver and release $\mathrm{CCl}_{3}$ radicals, a free radical that binds to lipoproteins and leads to peroxidation of lipids of endoplasmic reticulum ${ }^{28} . \mathrm{CCl}_{4}$ causes liver injury that is characterized by centrilobular necrosis that is followed by hepatic fibrosis ${ }^{29}$. In our study we performed paracetamol and carbon tetra chloride induced hepatotoxicity. In paracetamol induced hepatotoxicity, toxicant (Paracetamol) was given at 0 $\mathrm{hr}$ and followed by ethanol extract. In $\mathrm{CCl}_{4}$ induced hepatotoxicity toxicant $\mathrm{CCl}_{4}$ was administrated (at $2^{\text {nd }}$ and $3^{\text {rd }}$ day) along with ethanol extract from the bark 
Table 3: Anti oxidant activity of ethanol extracts from the bark of D.turbinatus

\begin{tabular}{|c|c|c|c|}
\hline \multirow{2}{*}{ Scavenging methods } & \multirow{2}{*}{ Positive control } & \multicolumn{2}{|c|}{$\mathrm{IC}_{50}$} \\
\hline & & EEDT & Standard \\
\hline DPPH scavenging activity & Ascorbic acid & $53.63 \pm 1.282^{* *}$ & $10.63 \pm 1.282$ \\
\hline Nitric oxide scavenging activity & Ascorbic acid & $47.01 \pm 3.197^{* * *}$ & $7.210 \pm 0.85$ \\
\hline Super oxide scavenging activity & Ascorbic acid & $45.72 \pm 5.299^{* *}$ & $14.39 \pm 0.94$ \\
\hline Reducing power method & Ascorbic acid & $43.90 \pm 2.866^{* * *}$ & $15.26 \pm 1.994$ \\
\hline
\end{tabular}

of $D$. turbintaus in dose dependent manner for 0 to 5 days, once/day. The ethanolic extract from the barks of $D$. turbinatus able to decrease the elevated biochemical parameters like SGOT, SGPT, ALP, cholesterol, bilirubin level in both carbon tetra chloride and paracetamol induced hepatotoxicity in rats and also significantly increased the total protein in the blood of treated animals with test drugs and silymarin. These findings suggest that ethanolic extract of $D$. turbinatus is effective in bringing the functional improvement of liver. Protection in hepatocyte by EEDT at $200 \mathrm{mg} / \mathrm{kg}$ and $400 \mathrm{mg} / \mathrm{kg}$ also was confirmed by histopathological studies of the liver for various groups animal. Anti oxidant activity shows that the drug extract has beneficial anti oxidant property with significant $\mathrm{IC}_{50}$ values with the reference standard of ascorbic acid.

Treatment with EEDT brought down the elevated levels of various biochemical parameters related to hepatic function and also restores the damage of liver cell. An overall result is concluded in these studies that the drug can be a therapeutic agent in liver damage in future. Hepatoprotective effect of EEDT may be due to its anti oxidant activity and ability to scavenging the free radicals which may be due to the presence of phenol and flavonoids in the extracts. However further studies are need to confirm involvement of cytochrome p450 enzyme inhibition to check the proper mechanism of liver protection from toxicity.

\section{Acknowledgement}

I am thankful to the Principal and Management of Creative Education Society's College of Pharmacy for providing all the facilities to complete my work and my senior colleague Dr. S. V. Suresh Kumar, HOD, Dept of Pharmacognosy for helping me in research work.

\section{References}

1. Ward FM, Daly MJ. Hepatic disease in: Clinical pharmacy and therapeutics. New York: Walker RC Edwards Churchill Living stone; 199 . p. 195-212.

2. William ML. Drug induced hepatotoxicity. The New England Journal of Medicine. 2003; 349:474-85.

3. Ramchadrasetty S, Quereshi AA, Viswaathswamy AHM, Patil T, Prakash T, et al. Hepatoprotective activity of Calotropis procera flower against paracetamol induced hepatic injury in rats. 2007; 78:451-4.

4. Biswas D, Gouda TS, Gowrishankr NL. Pharmacognostic study and establishment of quality parameters for medicinal plant of Dipterocarpaceae in Northeastern State Tripura. International Journal of Green Pharmacy. 2015; 9(S1):24-8.

5. Mc Cord JM. The evaluation of free radical and oxidative stress. American Journal of Medicine. 2001; 108:652-9.

6. Chatterjee A, Prakashi SC. The treatise on Indian medicinal plant. New Delhi: Publication and Information Directorate; 1995. p. 139.

7. Natkarni KM. Indian Material Medica. Bombay: Popular Prakashan; 1982. p. 456-7.

8. Kirtikar KR, Basu BD. Indian medicinal plant. Int Book Seller and Publisher; 2005. p. 288-90.

9. Gupta V, Keshari BB, Tiwari SK, et al. A review on anti diabetic action of Asanadi guna. Int J of Res Ayu Pharma. 2013; 4(5):638-46.

10. Rajendra K, Upadhay S. Free radical scavenging activity of medicinal plant of Tripura north east India. Natural Product Radiance. 2009; 8(2):117-22.

11. Haque MM, Choudhury SM, Hossain SM, Haque AM, Seraj S, Rahmatullah M. Ethnographic information and medicinal formulation of Mro Community of Gazalia union in the Bandarbans district of Bangladesh. 2012; 6(3):162-71. 
12. Akter R, Uddin SJ, Grice ID, Tiralongo E. Cytotoxic activity screening of Bangladeshi medicinal plant extract. Journal of Natural Medicine. 2014; 68(1):246-52.

13. Khiev $\mathrm{P}$, Kwon KO, Song $\mathrm{HH}$, Oh SR, Ahn KS, et al. Cytotoxic terpenes from the Dipterocarpus obtusifolius called in Cambodia. Chem Pharm Bull. 2012; 60(8):95561.

14. Veeraraghavan P. Expert consultant Committee for Purpose of Control and Supervision of Experiments on Animal (CPCSEA) Animal Welfare Division Government of India (Guide line No. 423, Annexure 2D of OECD); 2001 Sep 19.

15. Silva MGB, Agaga TP, Vasconcelos CFB, Perreira PA, Bruno AA, Costa IMA, et al. Acute and sub acute toxicity of Cassia occidentalis L stem and leaf in Wister rats. Journal of Ethno Pharmacology. 2011; 136:341-6.

16. Singh A, Handa SS. Hepatoprotective activity of Apium graveolens and Hygrophila auriculata against paracetamol and thioacetamide intoxication in rats. Journal of Ethno Pharmacology. 1995; 49:119-26.

17. Bhanwra S, Singh J, Khosla P. Effects of Azadirachta indica (Neem) leaf aqueous extracts on paracetamol induced liver damage in rats. Indian Journal of Physiology and Pharmacology. 2000; 44:64-8.

18. Bagban IM, Pal SP, Chaudhury A, Das SK, Gohil KJ, Bandari KK. Hepatoprotective activity of the methanolic extracts of Fagonia indica Burm in carbon tetra chloride induced hepatotoxicity in rats. Asian Pacific Journal of Tropical Biomedicine. 2012; (S1):245-9.

19. Yadav NP, Pal A, Shanker K, Dyaneshwar UB, Guptan AK, Darkar MP, Suman PSK, Synergistic effects of silymarin and standardized extract of Phyllanthus amarus against $\mathrm{CCl} 4$ induced hepato toxicity in ruttus norvegicus. Phyto Medicine. 2008; 15:1053-61.
20. Kumar SVS, Mishra SS. Hepatoprotective effect of extracts from Pergularia daemia Forsk. Journal of Ethno Pharmacology. 2006; 107:164-8.

21. Sanjay R, Mukharjee K, Saha BP, Mukherjee PK, et al. Anti oxidant activity of Nelombo nucifera. Journal of Ethno Pharmacology. 2006; 104:322-7.

22. Jain A, Soni M, Deb L, Jain AR, Raut S P, Gupta VB, et al. Anti oxidant and hepatoprotective activity of ethanolic and aqueous extracts of leaves. Journal of Ethno Pharmacology. 2008; 116:61-6.

23. Khan RA, Khan RM, Sahreen S, Ahmed M. Evaluation of phenolic contents and anti oxidant activity of various solvent extracts of Sonchus asper (L). Chemistry Central Journal. 2012; 6(1):1-7.

24. Biswas D, Yoganandam GP, Dey A, Deb L. Evaluation of antimicrobial and wound healing potential of ethanol extracts of Wedelia biflora (Linn) D.C leaves. Indian Journal of Pharmaceutical Sciences. 2013; 75(2): 156-61.

25. William ML. Drug induced hepatotoxicity. The New England Journal of Medicine. 2003; 349:474-85.

26. Hartmut J, Gorge GJ, Cederbaum AI, Hinson JA, Pessyre D, Lemaster JJ. Mechanism of hepato toxicity. Toxicology Science. 2002; 65:166-76.

27. Verma N, Khosa R. Hepatoprotective activity of leaves of Zanthoxylum armatum D.C in CCl4 induced hepatotoxicity in rats. Indian Journal of Biochemistry and Bio Physics. 2010; 47:124-7.

28. Singh B, Saxena AK, Chandan BK, Suri OP, Suri KA, Sathi NK. Hepatoprotective of verbenal in on experimental liver damage in rodents. Fitoterapia. 1998; 58:135-40.

29. Pandit A, Sachdeva T, Bafna P. Druginduced hepatotoxicity: A review. Journal of Applied Pharmaceutical Sciences. 2012; 2(5):233-43. 